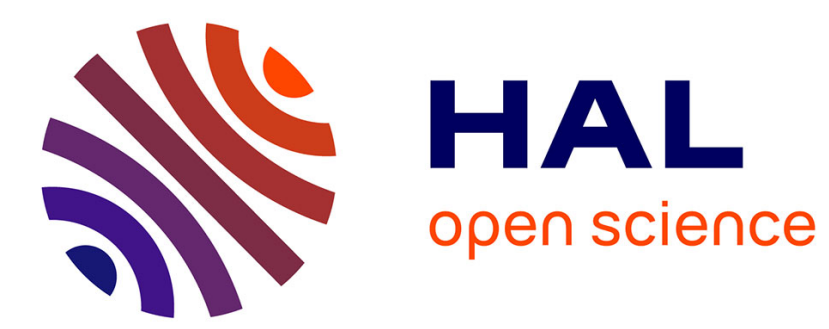

\title{
GRAIN REFINEMENT OF CVD TiC LAYERS BY AlCl3, ZrCl4 AND BCl3 IMPURITIES
}

\author{
A. Osada, M. Danzinger, R. Haubner, B. Lux
}

\section{To cite this version:}

A. Osada, M. Danzinger, R. Haubner, B. Lux. GRAIN REFINEMENT OF CVD TiC LAYERS BY AlCl3, ZrCl4 AND BCl3 IMPURITIES. Journal de Physique IV Proceedings, 1991, 02 (C2), pp.C2-557-C2-562. 10.1051/jp4:1991266 . jpa-00249856

\section{HAL Id: jpa-00249856 https://hal.science/jpa-00249856}

Submitted on 1 Jan 1991

HAL is a multi-disciplinary open access archive for the deposit and dissemination of scientific research documents, whether they are published or not. The documents may come from teaching and research institutions in France or abroad, or from public or private research centers.
L'archive ouverte pluridisciplinaire HAL, est destinée au dépôt et à la diffusion de documents scientifiques de niveau recherche, publiés ou non, émanant des établissements d'enseignement et de recherche français ou étrangers, des laboratoires publics ou privés. 
Colloque C2, suppl. au Journal de Physique II, Vol. 1, septembre 1991

GRAIN REFINEMENT OF CVD TIC LAYERS BY AlCl, $\mathrm{ZrCl}_{4}$ AND $\mathrm{BCl}_{3}$ IMPURITIES

A. OSADA* ${ }^{*}$ M. DANZINGER ${ }^{*}$, R. HAUBNER ${ }^{*}$ and B. LUX ${ }^{*}$

"Mitsubish1 Materials Corporation, 1-27-20 Nishi-Shinagawa, Shinagawa-ku, Tokyo 141, Japan

** Institute for Chemical Technology of Inorganic Materials, Technical University Vienna, Getreidemarkt 9/161, A-1060 Vienna, Austria

\begin{abstract}
The influence of small amounts of $\mathrm{AlCl}_{3}, \mathrm{ZrCl}_{4}$ and $\mathrm{BCl}_{3}$ on $\mathrm{CVD}$ of $\mathrm{TiC}$ with a $\mathrm{TiCl} 4 / \mathrm{H}_{2} / \mathrm{CH}_{4}$ gas mixture under reduced pressure was investigated. Grain refinement of TiC coatings could be obtained by adding dopant compounds at suitable concentrations. Their interactions are explained by the formation of co-deposited phases which interfere with the growth of TiC crystals and promote surface nucleation. The effectiveness of dopants to decrease the grain size is explained by the formation of thin films on the growing TiC crystals having a different chemical bonding than Tíc.
\end{abstract}

\title{
1. INTRODUCTION
}

Cutting tools coated with TiC by chemical vapor deposition (CVD) are widely used today because of their high wear resistance and toughness. Many investigations have been carried out to further enhance the cutting performance of coated tools. One approach is to develop new coating materials such as mixed layers (e.g. Ti-zr-C[1], Al-O-N [2]) or mixed crystals (e.g. Ti-Al-N [3]. TiB-C [4]). Another approach is to improve the properties of the coating materials by forming a finer grained structure or a more uniform layer thickness, which can be achieved by the improvement of the technological process, for example by controling impurities [5-6].

The ternary systems of Ti-Al-C, Ti-Zr-C and Ti-B-C have already been investigated using the CVD method [1,7] and the PVD method [3,8-9]. It was also reported $[7,10]$ that $A l$ or $M g$ as dopants in the deposition process of TiC had a positive catalytic influence on the deposition rate and the grain refinement. However, there is still no theoretical explanation for the mechanism of this influence. In the work reported here the influence of small amounts of $\mathrm{AlCl}_{3}, \mathrm{ZrCl}_{4}$ and $\mathrm{BCl}_{3}$ additions on the deposition process and on the morphologies of TiC coatings was investigated.

\section{EXPERIMENTAL PROCEDURE}

The experimental setup for TiC deposition is described in Fig.1. The TiC CVD process was carried out with the system $\mathrm{TiCl}_{4} / \mathrm{H}_{2} / \mathrm{CH}_{4}$ under the conditions indicated in Table 1 . ISO K20 cemented carbide (commonly called $W C-C o)$ was used for the substrates. Before deposition all substrates were cleaned with methanol. The solid impurities $\mathrm{AlCl}_{3}$ and 
$\mathrm{ZrCl}_{4}$ were sublimated. The doping concentration was controlled by the temperature in a sublimator and the flow rate of the $\mathrm{H}_{2}$ carrier gas. A known quantity of $\mathrm{BCl}_{3}$ was feed into an Ar-filled bottle with constant volume. During the $\mathrm{BCl}_{3}$ addition to the CVD reactor the amount of $B$ added was controlled by the pressure drop occurring in the bottle.

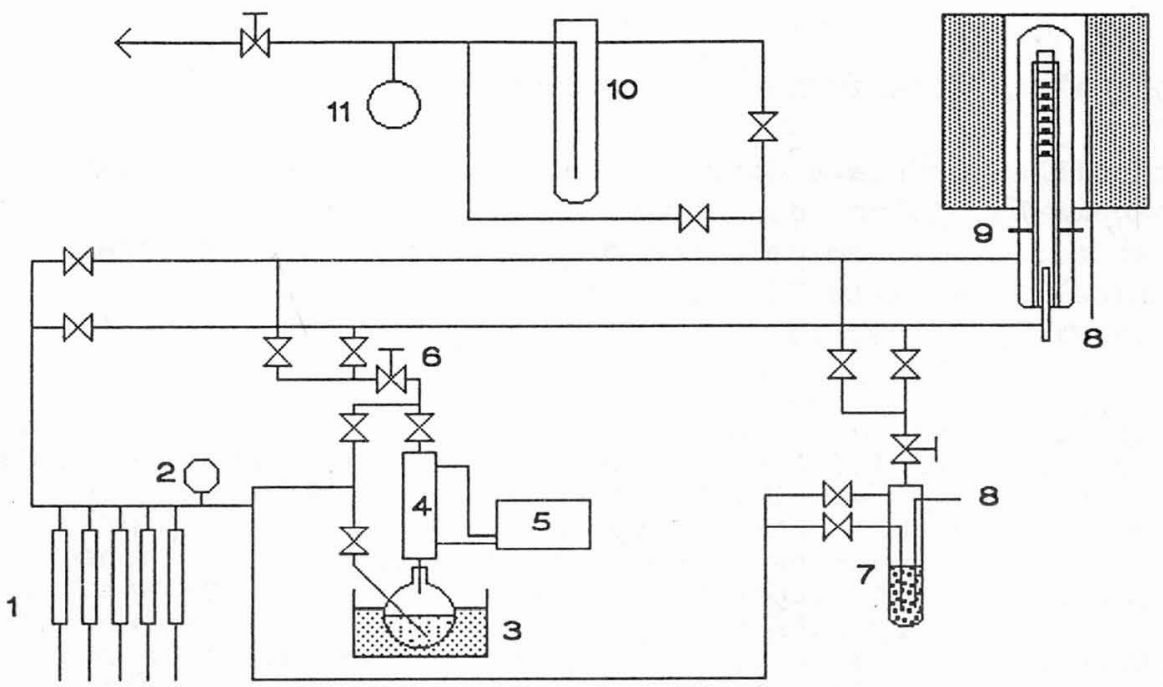

1. Flow meter

2. Pressure gauge

3. $\mathrm{TiCl}_{4}$ evaporator

4. Saturator

5. Isothermal water-circulating unit

6. Regulating valve

7. Sublimator for impurities

8. Thermocouple

9. Reaction chamber

10. Liquid $\mathrm{N}_{2}$ cold trap

11. Mercury pressure gauge

Fig.1: Schematic diagram of CVD equipment

Table 1: Experimental conditions

\begin{tabular}{|c|c|c|}
\hline Constants & $\begin{array}{l}\text { Temperature } \\
\text { Pressure } \\
\text { Total flow rate } \\
\text { TiCl4 flow rate } \\
\mathrm{CH}_{4} \text { flow rate } \\
\text { Deposition time }\end{array}$ & $\begin{aligned}: & 1050^{\circ} \mathrm{C} \\
\vdots & 50 \mathrm{torr} \\
: & 20 \mathrm{l} / \mathrm{h} \\
\vdots & 1 \mathrm{l} / \mathrm{h} \\
\vdots & 2 \mathrm{l} / \mathrm{h} \\
& 1 \mathrm{~h}\end{aligned}$ \\
\hline
\end{tabular}

Variables Doping concentrations
$\mathrm{AlCl}_{3}: 0,10,1.000,100.000\left(\mathrm{~mol}-\mathrm{ppm}^{*}\right)$
$\mathrm{BCl}_{3}: 0,1.000,100.000,1.000 .000\left(\mathrm{~mol}-\mathrm{ppm}^{*}\right)$ (carried by $51 / \mathrm{h}$. Ar)
$\mathrm{ZrCl}_{4}: 0,10,1.000,10.000\left(\mathrm{~mol}-\mathrm{ppm}^{*}\right)$ (carried by $51 / \mathrm{h} \mathrm{H}_{2}$ )

*: The unit "mol-ppm" refers to the concentration per mole $\mathrm{TiCl}_{4}$ and not to the total gas volume. 


\section{RESULTS}

\subsection{Growth rate}

The TiC growth rate did not change when $\mathrm{ZrCl}_{4}$ was added as a dopant, but increased with the addition of $\mathrm{AlCl}_{3}$ and of $\mathrm{BCl}_{3}$. With $\mathrm{AlCl}_{3}$ the growth rate increased at low and decreased at high doping concentrations. However, for $\mathrm{BCl}_{3}$, it increased with doping concentration higher than 100,000 ppm (Fig.2).

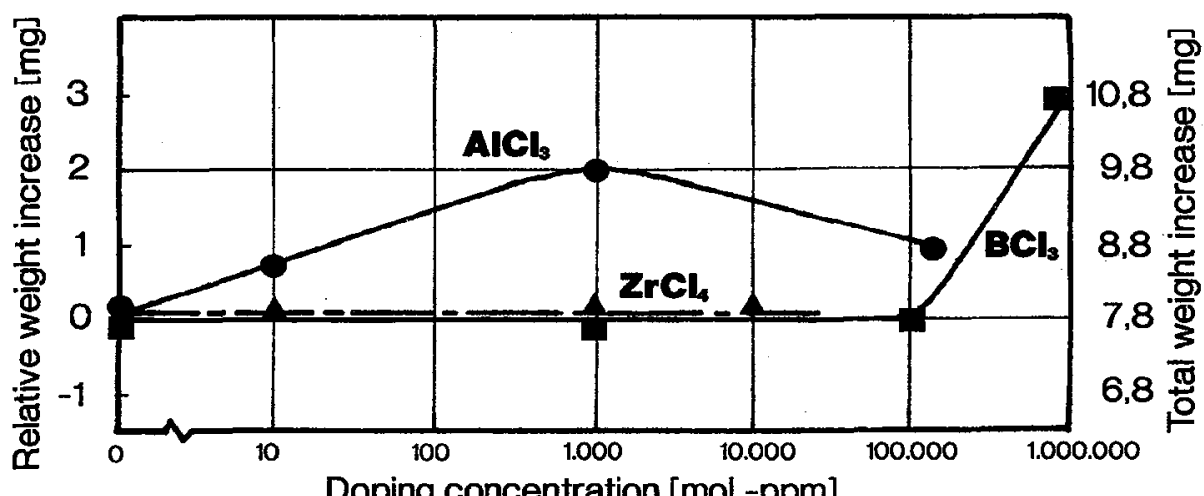

Fig.2: Influence of impurities on the deposition rate of the $\mathrm{TiC}$ coating

\section{2. $x$-ray diffraction analysis}

Table 2 lists the solid phases deposited after the CVD reaction with different impurities, and concentrations. For $\mathrm{AlCl}_{3}$ and $\mathrm{ZrCl}_{4}$ no phases other than TiC and eta-phase $\left(\mathrm{W}_{6} \mathrm{CO}_{6} \mathrm{C}\right)$ could be detected, while for $\mathrm{BCl}_{3}$ the $\mathrm{TiB}_{2}$ and CoWB peaks were observed at dopant amounts of $100,000 \mathrm{ppm}$ and higher.

Table 2: Influence of impurities on deposited phases and relative $\mathrm{x}$-ray intensities

\begin{tabular}{|c|c|c|c|c|}
\hline concentrations & $\begin{array}{l}\text { relative X } \\
\mathrm{AlCl}_{3}\end{array}$ & $x-r a y$ & $\begin{array}{l}\text { intensities } \\
\mathrm{ZrCl}_{4}\end{array}$ & $\begin{array}{l}\text { of deposited phases } \\
\mathrm{BCl}_{3}\end{array}$ \\
\hline $0 \mathrm{ppm}$ & $\begin{array}{l}\text { Tic }(100 \%) \\
\text { eta }(<5 \%)\end{array}$ & & $\begin{array}{l}\text { Tic }(100 \%) \\
\text { eta }(<5 \%)\end{array}$ & $\begin{array}{l}\text { Tic }(100 \%) \\
\text { eta }(10 \%)\end{array}$ \\
\hline $10 \mathrm{ppm}$ & $\begin{array}{l}\text { TiC }(100 \%) \\
\text { eta }(<5 \%)\end{array}$ & & $\begin{array}{l}\text { TiC }(100 \%) \\
\text { eta }(<5 \%)\end{array}$ & 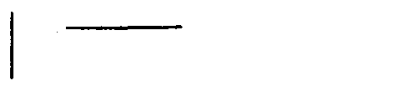 \\
\hline
\end{tabular}

\begin{tabular}{|c|c|c|c|c|c|c|c|}
\hline 1,000 & ppm & $\begin{array}{l}\text { Tic }(100 \%) \\
\text { eta }(<5 \%)\end{array}$ & $\begin{array}{ll}\text { TiC } & (100 \%) \\
\text { eta } & (<5 \%)\end{array}$ & $\begin{array}{l}\text { Tic } \\
\text { eta }\end{array}$ & $\begin{array}{r}(100 \%) \\
(12 \%)\end{array}$ & & \\
\hline 10,000 & $\mathrm{ppm}$ & $\longrightarrow$ & $\begin{array}{l}\text { Tic }(100 \%) \\
\text { eta }(<5 \%)\end{array}$ & $\longrightarrow$ & - & & \\
\hline 100,000 & ppm & $\begin{array}{l}\text { Tic }(100 \%) \\
\text { eta }(<5 \%)\end{array}$ & $\longrightarrow$ & $\begin{array}{l}\text { Tic } \\
\text { eta }\end{array}$ & $\begin{array}{l}(100 \%) \\
(10 \%) .\end{array}$ & $\begin{array}{l}\text { CoWB } \\
\mathrm{TiB}_{2}\end{array}$ & $\begin{array}{l}(5 \%) \\
(3 \%)\end{array}$ \\
\hline 000,000 & ppm & $\longrightarrow$ & $\longrightarrow$ & $\begin{array}{l}\mathrm{TiC} \\
\mathrm{TiB}\end{array}$ & $\begin{array}{l}(50 \%) \\
(100 \%)\end{array}$ & & \\
\hline
\end{tabular}




\subsection{Grain size}

The changes of the TiC crystal habit at different doping concentrations and impurities are shown in Fig.3. Grain refinement of the Tic coating could be obtained by doping with $\mathrm{AlCl}_{3}$ or $\mathrm{BCl}_{3}$. For both impurities there were so-called "critical concentrations" at which the grain refinement effect showed a maximum [11]. Below the critical concentrations the grain size decreased with increasing dopant concentration and above it increased with increasing dopant concentration. The critical concentrations were different for each impurity. The Tic crystal morphology changed remarkably when $\mathrm{BCl}_{3}$ exceeded the critical concentration. This change could be due to the increasing amounts of $\mathrm{TiB}_{2}$ deposition.

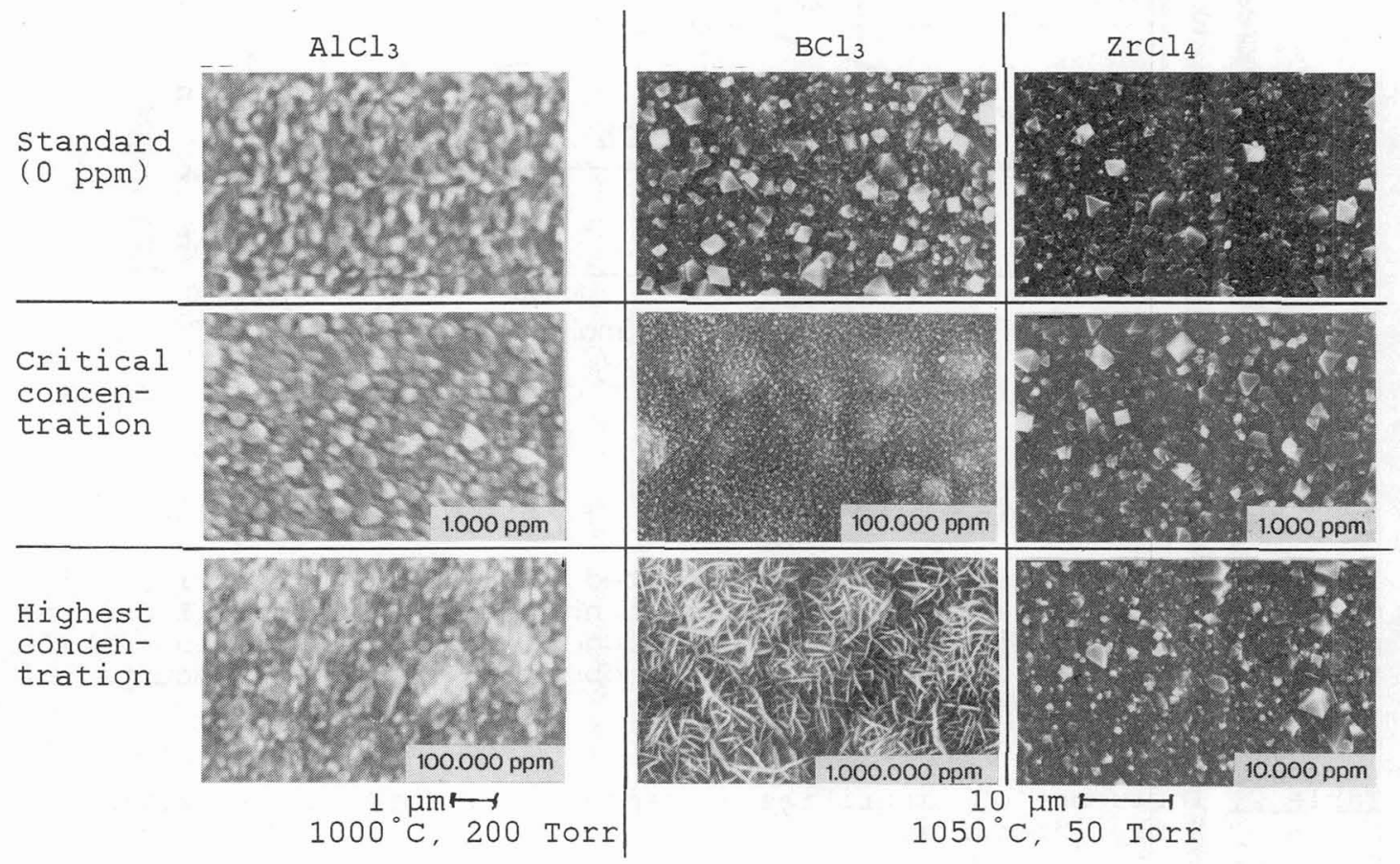

Fig.3: Grain size of Tic coatings deposited at different impurity concentrations

\section{DISCUSSION}

The grain refinement of the TiC coating by $\mathrm{AlCl}_{3}$ or $\mathrm{BCl}_{3}$ can be explained. by the formation of new phases which were co-deposited simultaneously with the TiC by the reaction between the doped impurity and the reaction gas. Similar to an intermediate layer in a multilayer coating, a co-deposited phase inhibits the continued growth of the crystals and forces a new nucleation step on the surface, which basically promotes the grain refinement of the main constituent.

In the case of $\mathrm{BCl}_{3}$ doping, $\mathrm{X}$-ray diffraction and electron probe micro analysis showed $\mathrm{TiB}_{2}$ formation and co-deposition when high $\mathrm{BCl}_{3}$ amounts (above 100,000 ppm) were added. The co-deposition of the two phases leads in this case to the grain refinement. However with $\mathrm{AlCl}_{3}$ and $\mathrm{ZrCl}_{4}$ no co-deposited phases could be detected, either by X-ray diffraction or by electron probe micro analysis, at any of the 
concentrations. This might be due to the very small amounts of the co-deposited phase, i.e. amounts below the limit of detection ( 0.1 at\%) for electron probe micro analysis. The reason that such small amounts of the co-deposited phase influence the grain size could be a difference in chemical bonding. These films are very thin and could even be monomolecular. For $\mathrm{AlCl}_{3}$ addition the carbide $\mathrm{Al}_{3} \mathrm{C}_{4}$, which has an ionic bonding, might be the co-deposited phase. such a mechanism could be explained as follows:

Stage 1: Tic crystals grow on the substrate surface.

stage 2: A very small amount of $\mathrm{Al}_{3} \mathrm{C}_{4}$ (e.g. an extremly thin film) might deposit on the Tic crystal facets. Such a simultaneous deposition of a phase with ionic bonding should stop the further growth of Tic crystals.

stage 3: New heterogeneous nucleation of TiC must occur on this extremly thin film.

The consequence is a reduction of the grain size. This mechanism is shown schematically in Fig.4. Just a small amount of $\mathrm{Al}_{\mathrm{x}} \mathrm{C}_{y}$ on the crystal surface should restrain the $\mathrm{TiC}$ crystal growth more effectively than $\mathrm{ZrC}$ or $\mathrm{TiB}_{2}$ because of the greater difference in chemical bonding as well as the structural difference between the TiC (metalic bonding, cubic structure) and $A l_{x} C_{Y}$ (ionic bonding) than between the TiC and $\mathrm{ZrC}$ or $\mathrm{TiB}_{2}$ (metallic bonding). Table 3 shows the chemical bonding and structures of selected hard materials.

For the $\mathrm{ZrCl}_{4}$ additions, no effect on the grain refinement was observed. It can be assumed that a new nucleation of Tic is not necessary during the co-depositon of the two phases because their chemical bondings and structures are similar to those of TiC.

stage 1: TiC crystal growth

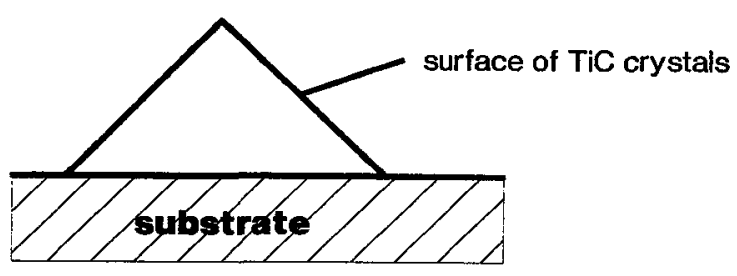

Stage 2: Formation of an extremly thin film of $A l_{x} C_{y}$ and stopping of the Tic crystal growth.

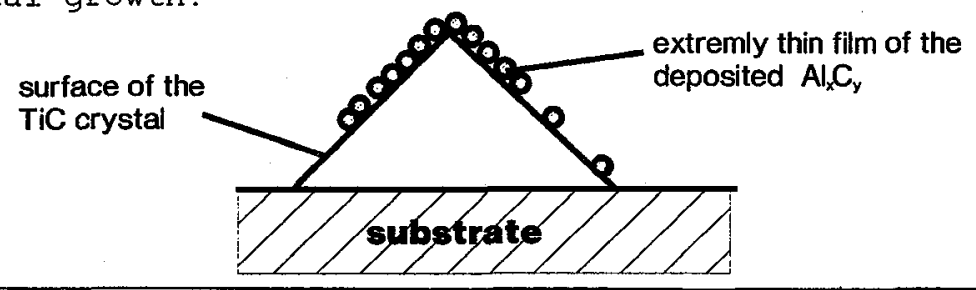

Stage 3: Nucleation of TiC on the extremly thin film

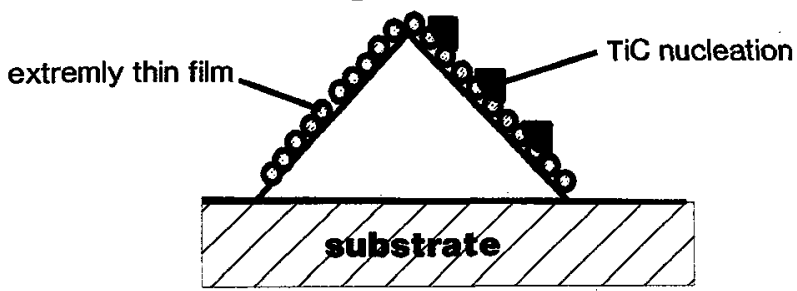

Fig. 4: Mechanism of the grain refinement of the Tic coating by the co-deposition of $\mathrm{Al}_{X} C_{Y}$ 
Table 3: Chemical bonding and structures of hard materials

\begin{tabular}{l|l|l} 
Phase & Bonding & structure \\
\hline TiC & metallic & cubic \\
TiN & metallic & cubic \\
ZrC & metallic & cubic \\
ZrN & metallic & cubic \\
$\mathrm{TiB}_{2}$ & metallic & hexagonal \\
$\mathrm{Al}_{4} \mathrm{C}_{3}$ & ionic & hexagonal \\
$\mathrm{AlN}$ & ionic & hexagonal
\end{tabular}

Similar results were reported by P.Wilhartitz et al.[12]. They analyzed $\mathrm{Al}_{2} \mathrm{O}_{3}-\mathrm{CVD}$ with $\mathrm{CS}_{2}$ additions using SIMS and reported that carbon incorporated in the $\mathrm{Al}_{2} \mathrm{O}_{3}$ coating appeared to be responsible for the grain refinement of this coating [13]. These results can be explained by the same mechanism: The epitaxial growth of the crystal facets is stopped because of the co-deposition of carbon which has a different chemical bonding (covalent) than $\mathrm{Al}_{2} \mathrm{O}_{3}$ (ionic); new nucleations have to occur to continue the deposition, which leads to the grain refinement.

\section{CONCLUSION}

Small amounts of $\mathrm{AlCl}_{3}$ and $\mathrm{BCl}_{3}$ added to the commonly used $\mathrm{TiCl}_{4} / \mathrm{H}_{2} / \mathrm{CH}_{4}$ CVD gas mixture can strongly influence the layer growth and the grain size, while $\mathrm{ZrCl}_{4}$ doping showed no influence. The differences in the influence on the grain size due to the various impurities can be explained by the differences in chemical bonding between the deposited impurity compounds and the TiC.

\section{ACKNOWLEDGEMENT}

The authors wish to thank Mitsubishi Materials Corporation for financial support and for permission to publish these results, as well as Mr. Yoshimura for his continued interest in this work.

\section{REFERENCES}

11/ Iiyoshi H, Doctoral thesis, Techn. Univ. Vienna (1987)

/2/ Reiter N, VDI Berichte Nr.624 (1986) 167

/3/ Knotek O, et al., J.Vac.Sci.Technol. A, 4(6) (1986) 2695

/4/ Karner H, Laimer'J, Störi H, $12^{\text {th }}$ Plansee Seminar, Vol.3 (1989) 495

/5/ Altena $H$, Colombier $C$, Lebl A, Lindström J, Lux B, $4^{t h}$ Euro CVD, Eindhoven (1983) 428

/6/ Altena H, Colombier C, Lux B, 4th Euro CVD, Eindhoven (1983) 451

/7/ Van den Berg H, König U, Reiter N, $6^{\text {th }}$ Euro CVD, Jerusalem (1987) 114

/8/ Holleck H, Metal, 7 (1989) 614

19/ Mitterer C, Rauter M, Rödhammer P, $12^{\text {th }}$ Plansee Seminar, Vol. 3 (1989) 411-425

/10/ Van den Berg H, König U, Reiter N, FRG.Pat. DE3544975C1 (1987)

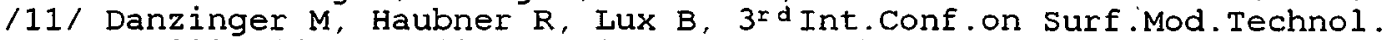
pp.829-834, Aug.28-Sept.1, 1990, Neuchatel, Switzerland

112/ Wilhartitz $P$, Grasserbauer M, Aitena H, Lux B, Surface and Interface Analysis, 8 (1986) 159-165

113/ Danzinger M, Peng X.X, Haubner R, Lux B: $8^{\text {th }}$ Euro CVD, Glasgow (1991) (in preparation) 